\title{
Mercury and Halogens in Coal-Their Role in Determining Mercury Emissions From Coal Combustion
}

\section{Introduction}

Mercury $(\mathrm{Hg})$ is a toxic pollutant. In its elemental form, gaseous mercury has a long residence time in the atmosphere, up to a year, allowing it to be transported long distances from emission sources. Mercury can be emitted from natural sources such as volcanoes, or from anthropogenic sources, such as coal-fired powerplants. In addition, all sources of $\mathrm{Hg}$ on the Earth's surface can re-emit it from land and sea back to the atmosphere, from which it is then redeposited.

Mercury in the atmosphere is present in such low concentrations that it is not considered harmful. Once $\mathrm{Hg}$ enters the aquatic environment, however, it can undergo a series of biochemical transformations that convert a portion of the $\mathrm{Hg}$ originally present to methylmercury, a highly toxic organic form of mercury that accumulates in fish and birds. Many factors contribute to creation of methylmercury in aquatic ecosystems, including $\mathrm{Hg}$ availability, sediment and nutrient load, bacterial influence, and chemical conditions. In the United States, consumption of fish with high levels of methylmercury is the most common pathway for human exposure to Hg, leading the U.S. Environmental Protection Agency (EPA) to issue fish consumption advisories in every State (fig. 1).

The EPA estimates that 50 percent of the $\mathrm{Hg}$ entering the atmosphere in the United States is emitted from coal-burning utility powerplants (U.S. Environmental Protection Agency, 2011a). An EPA rule, known as MATS (for Mercury and Air Toxics Standards), to reduce emissions of $\mathrm{Hg}$ and other toxic pollutants from powerplants, was signed in December 2011 (U.S. Environmental Protection Agency, 2012). The rule, which is currently under review, specifies limits for $\mathrm{Hg}$ and other toxic elements, such as arsenic (As), chromium (Cr), and nickel (Ni). MATS also places limits on emission of harmful acid gases, such as hydrochloric acid $(\mathrm{HCl})$ and hydrofluoric acid (HF). These standards are the result of a 2010 detailed nationwide program by the EPA to sample stack emissions and thousands of shipments of coal to coal-burning powerplants (U.S. Environmental Protection Agency, 2011b,c). The United States is the only nation to have collected such detailed information for $\mathrm{Hg}$ in both its coal and its utility emissions.
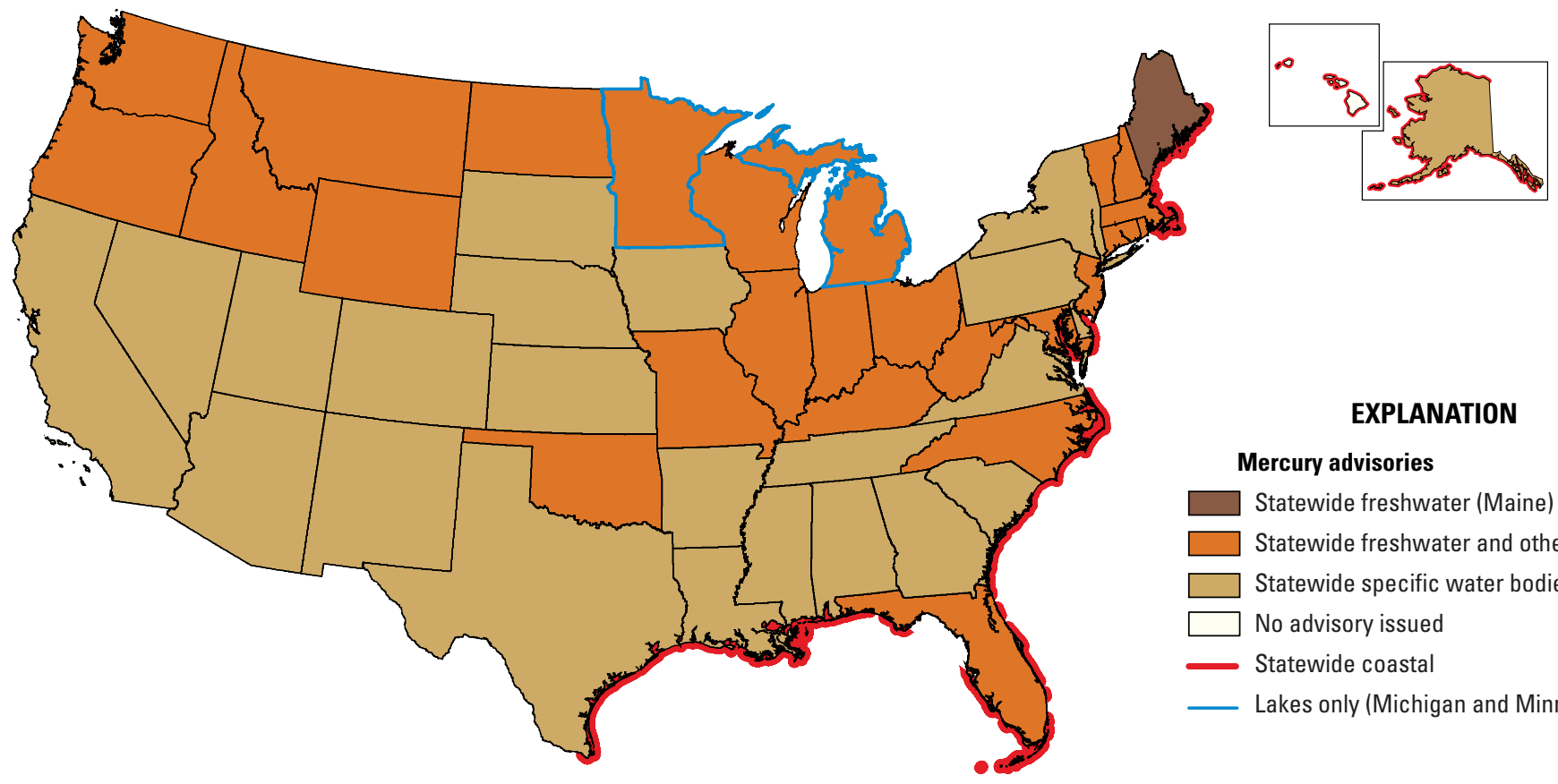

EXPLANATION

Mercury advisories

Statewide freshwater (Maine)

Statewide freshwater and other advisories Statewide specific water bodies

No advisory issued

Statewide coastal

Lakes only (Michigan and Minnesota)

Figure 1. U.S. water bodies for which the Environmental Protection Agency issued fish consumption advisories in 2010. Advisories include statewide freshwater advisories (Maine), statewide freshwater advisories with additional advisories on specific water bodies, statewide advisories for specific water bodies, and statewide coastal advisories. In Michigan and Minnesota, statewide advisories are for lakes only. There are no fish consumption advisories for $\mathrm{Hg}$ in the District of Columbia and Puerto Rico; in Hawaii, there are only coastal advisories. Figure modified from U.S. Environmental Protection Agency. Alaska, Hawaii, and Puerto Rico not to common scale. 


\section{U.S. Geological Survey Coal Data}

While U.S. Geological Survey (USGS) results were not used in developing the EPA MATS standards, the USGS domestic and international coal databases and research on trace elements in coal contain much information that is relevant to understanding how $\mathrm{Hg}$ in coal occurs and why some coals contain more Hg than others. Since the 1980s, the USGS has compiled data on the quality and chemical composition of U.S. coals by using samples that represent the entire thickness of a coal bed in the ground (Bragg and others, 1998). This Coal Quality Database, known as COALQUAL, contains data on the chemical composition of more than 7,000 U.S. coal samples and includes results for $\mathrm{Hg}$, trace elements, and other important properties of coal, such as its ash content- the amount of inorganic material present - as well as its moisture and its sulfur content. Using COALQUAL, Tewalt and others (2001) determined a mean Hg concentration of 0.17 parts per million (ppm) for in-ground coal for the entire United States.

\section{Comparison of USGS and EPA Coal Databases}

In 1999, and again in 2010, the EPA compiled data for coal shipments delivered to U.S. power stations. The 2010 data, which were used in developing the MATS standards, give a mean $\mathrm{Hg}$ concentration of about $0.12 \mathrm{ppm}$ for delivered coal, much less than USGS results (0.17) for in-ground coal (fig. 2). The difference between the USGS and EPA results is explained by the fact that some coals, especially those high in sulfur, undergo preparation (cleaning) prior to delivery. The cleaning process reduces the amount of mineral matter present in the coal, such as pyrite $\left(\mathrm{FeS}_{2}\right)$, and constituents that may be associated with mineral matter, such as sulfur. As one of the benefits of coal cleaning, $\mathrm{Hg}$ associated with mineral matter is reduced in many cases, thereby accounting for lower average $\mathrm{Hg}$ values in the EPA databases when compared to the USGS results.

The EPA databases also differ in the geographic distribution of samples when compared to that of COALQUAL. COALQUAL contains a greater proportion of samples from the Appalachian Basin, which in general have higher mercury contents than low-sulfur Western coals, such as those in the Powder River Basin (PRB) of Wyoming and Montana. Use of PRB coals has increased markedly during the last two decades, a trend that is reflected in the EPA databases for delivered coal when compared to values for in-ground coal as determined from COALQUAL. Nonetheless, COALQUAL is very useful in showing how U.S. coals differ by location and by rank, a classification based primarily on the heating value of coal; low-rank coals include lignite and subbituminous whereas bituminous and anthracite are higher rank. COALQUAL is also useful in comparing U.S. coal with international samples.

Figure 2. Graphs show a comparison of concentrations of mercury $(\mathrm{Hg})$, in parts per million (ppm) on a dry basis, by percent of the number of samples determined for U.S. Geological Survey Coal Quality (COALQUAL) database and U.S. Environmental Protection Agency Information Collection Request (ICR) databases for 1999 and for 2010, Parts II and III. Rightmost column shows the percentage of samples in each database that exceeds $0.30 \mathrm{ppm} \mathrm{Hg}$; all samples are included in the arithmetic means, median concentrations, and sample numbers shown. Figure modified from Kolker and Quick (in press).
A. U.S. Geological Survey database

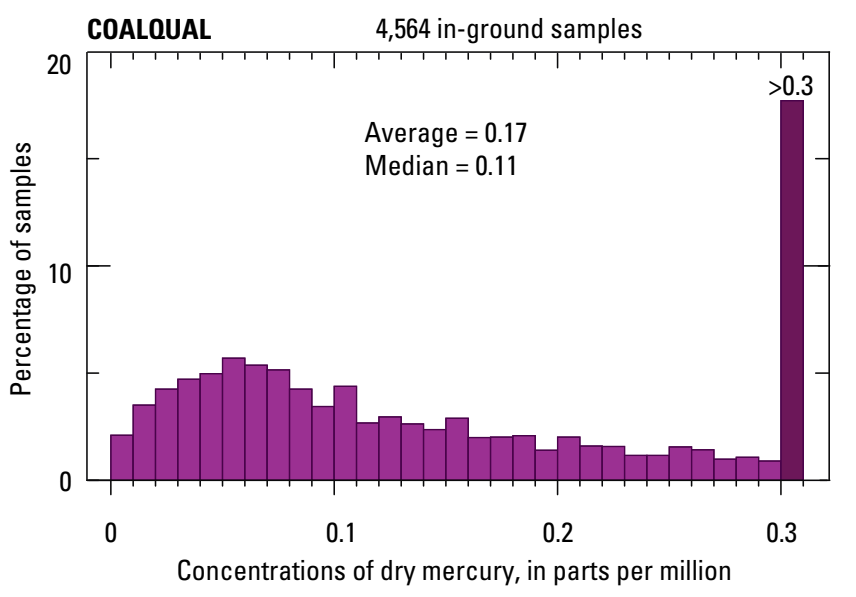

B. U.S. Environmental Protection Agency databases
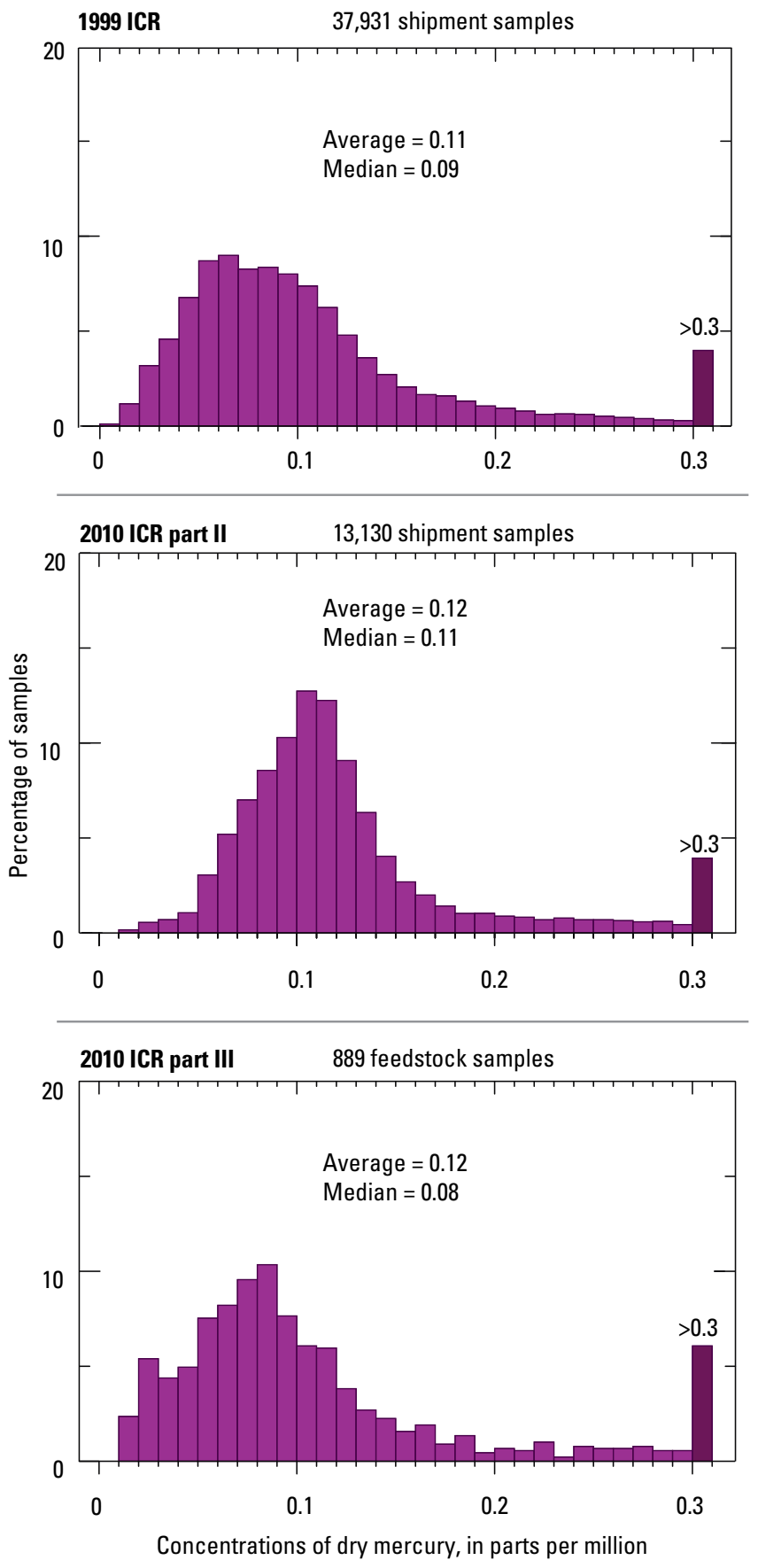


\section{International Coal Data}

Seven countries - China, the United States, India, Australia, South Africa, the Russian Federation, and Indonesia - listed in descending order of production, accounted for more than 90 percent of the hard coal produced during 2010 (table 1). Of these countries, detailed nationwide surveys of $\mathrm{Hg}$ distribution in coal are available only for the United States and China. China is both the world's largest producer and largest user of coal (International Energy Agency (IEA), 2011).

Recent compilations of average concentrations (means) for $\mathrm{Hg}$ in Chinese commercial coal range in value from 0.15 to $0.19 \mathrm{ppm}$, based on analysis of thousands of samples. One such compilation, the USGS World Coal Quality Inventory (WoCQI), is a publicly available database that includes chemical analyses and other relevant information for 1,580 coal samples from 57 countries (Tewalt and others, 2010). The USGS examined 305 samples of Chinese coal in WoCQI (excluding 23 samples of cleaned coal that the WoCQI listed) and determined their mean value to be $0.16 \mathrm{ppm} \mathrm{Hg}$ (fig. $3 A$ ). A recent study by Dai and others (2012) gives a mean value of $0.163 \mathrm{ppm} \mathrm{Hg}$ for 1,666
Table 1. Production data by country, listed in order of hard coal production.

[Values are in millions of metric tons (Mt) from 2010 data from International Energy Agency (2011)]

\begin{tabular}{lcc}
\hline \multicolumn{1}{c}{ Country } & Hard coal & Brown coal \\
\hline China & 3,162 & $*$ \\
United States & 932 & 65 \\
India & 538 & 33 \\
Australia & 353 & 67 \\
South Africa & 255 & 0 \\
Russian Federation & 248 & 76 \\
Indonesia & 173 & 163 \\
Others & 525 & 639 \\
\cline { 2 - 3 }$\quad$ World total & $\mathbf{6 , 1 8 6}$ & $\mathbf{1 , 0 4 3}$ \\
\hline
\end{tabular}

${ }^{*}$ Brown coal is included in hard coal data. The seven countries listed accounted for more than 90 percent of hard coal production.

\section{A. People's Republic of China}

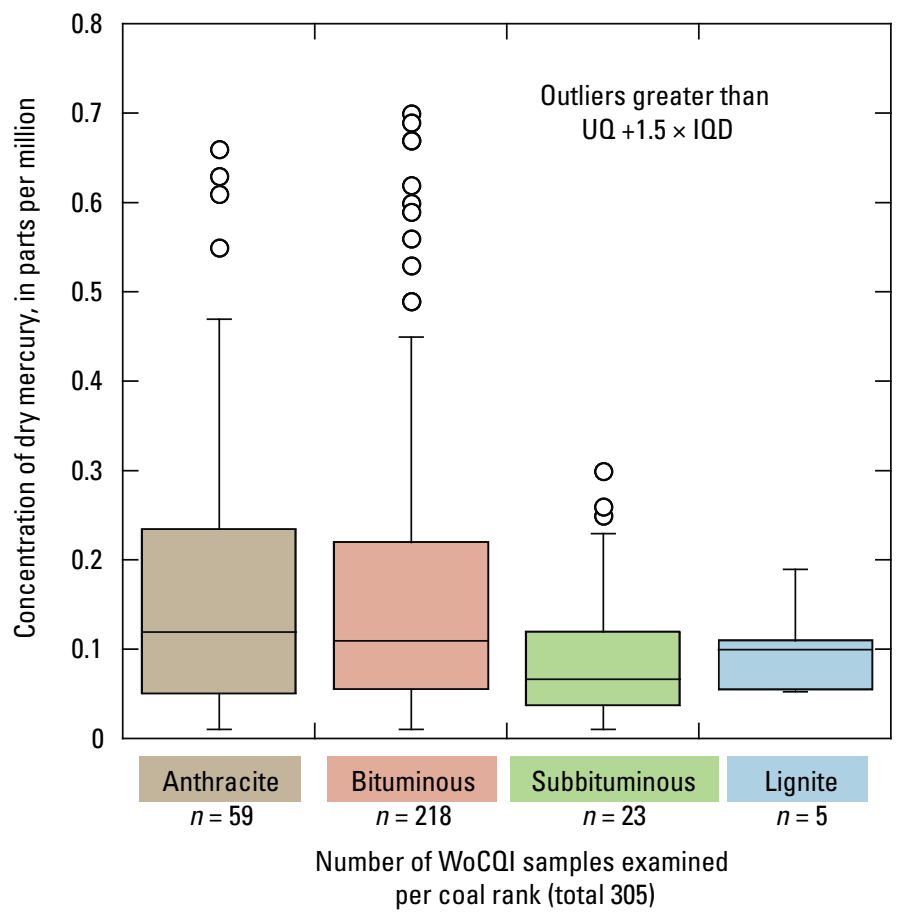

\section{B. Guizhou Province}

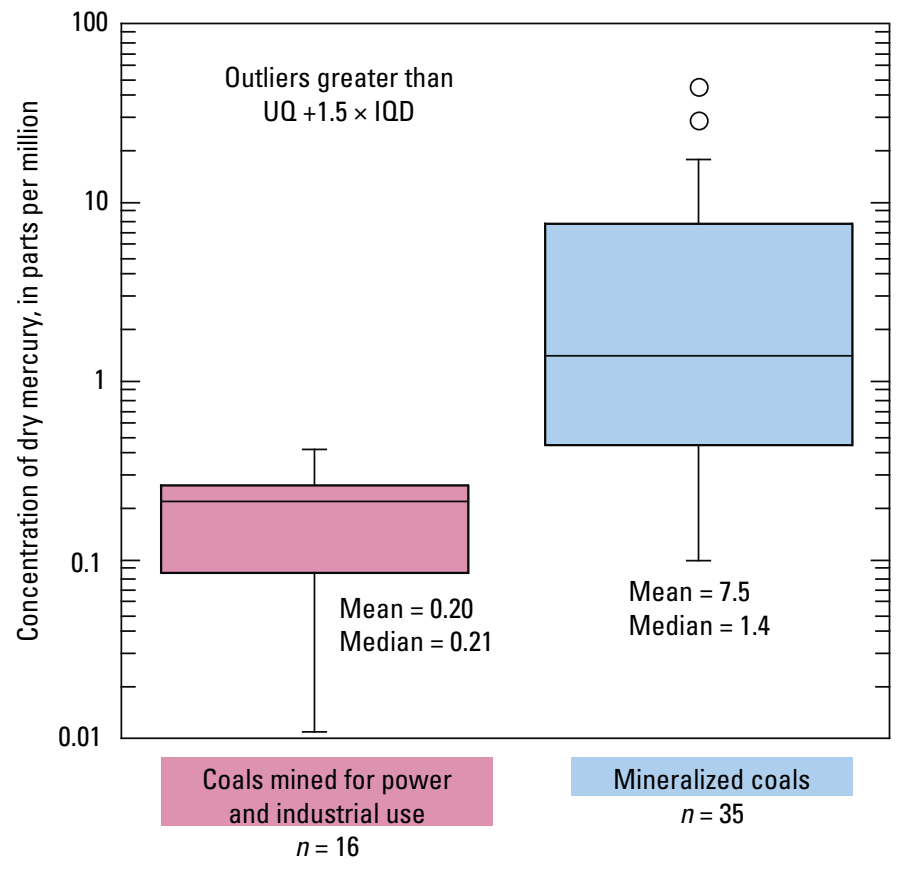

Number of WoCOl samples examined (total 51)

Figure 3. Compilation of U.S. Geological Survey results for mercury $(\mathrm{Hg})$ in Chinese coal, expressed in parts per million (ppm) on a dry basis. Data are shown as boxplots where each box encloses 50 percent of the data range and the median value is shown as a horizontal line. The top and bottom of the box, defined as the upper and lower quartiles, indicate \pm 25 percent of the sample population. The interquartile distance (IOD) is shown by the box height. Outliers are defined as either greater than the upper quartile (UO) plus 1.5 times the IOD or less than the lower quartile minus 1.5 times the IOD. $A$, Comparison of commercial coals mined throughout China by coal rank, including lignite, subbituminous, bituminous, and anthracite coals, listed in order of increasing rank. Plot includes 305 samples from 25 provinces and autonomous regions. Results give an overall mean mercury content of $0.16 \mathrm{ppm}$. From Belkin and others (2006) and Tewalt and others (2010). $B$, Comparison of commercial coals mined in Guizhou Province with Guizhou Province mineralized coals that are enriched in trace elements such as $\mathrm{Hg}$. For Guizhou Province, the mean $\mathrm{Hg}$ content of mineralized coals is nearly 40 times that of coals mined for power generation and industrial use. Inclusion of such mineralized coals in database compilations has led to past overestimates of the $\mathrm{Hg}$ content of Chinese coals. Data from Belkin and others (2006) and Tewalt and others (2010). WoCQI, World Coal Quality Inventory.

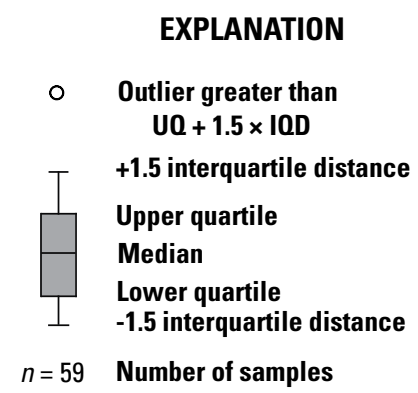


samples of Chinese coal, which is virtually identical to that determined by the USGS from WoCQI data.

These recent results for China contradict previous estimates that had implied that the $\mathrm{Hg}$ content of Chinese coal was much higher than that of U.S. coal. This impression probably resulted because the earlier compilations of the $\mathrm{Hg}$ content of coal used for the Chinese utility sector had included mercury- (and arsenic-) enriched mineralized coals, which are present locally in some parts of China - in Guizhou Province, for example - and were used primarily for domestic (as opposed to industrial and utility) purposes (fig. $3 B$ ).

Information for the next five largest producers of hard coal during 2010 - India, Australia, South Africa, the Russian Federation, and Indonesia - is more limited, and, with the exception of Australia, and possibly of the Russian Federation, does not allow nationwide calculations of means for $\mathrm{Hg}$ in coal in these countries. For India, Australia, and the Russian Federation, USGS coal sampling is limited to specific study sites that exclude important coal-producing regions. In South Africa, USGS sampling is more extensive, but the number of samples is still too few to allow determination of a nationwide mean for $\mathrm{Hg}$. New studies that improve sampling of coal and of emissions in major coal-using countries other than China and the United States could provide better estimates of the extent to which these countries contribute to global emissions of $\mathrm{Hg}$.

\section{Halogens in Coal and Their Influence on Mercury Capture}

Halogens are elements in a group that includes fluorine (F), chlorine $(\mathrm{Cl})$, bromine $(\mathrm{Br})$, and iodine $(\mathrm{I})$; they have similar chemical properties, and they form negatively charged ionic species. At high temperatures in the boilers of coal-fired powerplants, $\mathrm{Hg}$ from coal exists primarily in the form of gaseous elemental mercury $\left(\mathrm{Hg}^{0}\right)$. Air-pollution control devices (APCDs) present in modern coal-fired powerplants have little capacity to capture $\mathrm{Hg}^{0}$ because it is extremely nonreactive and insoluble. Halogens are important because they can convert $\mathrm{Hg}^{0}$ to oxidized forms of $\mathrm{Hg}$ at temperatures present in the flue gas of powerplants (fig. 4). This oxidized $\mathrm{Hg}$ combines with halogens, rendering these $\mathrm{Hg}$-halogen

\section{A. Gaseous $\mathrm{Hg}$}

\section{B. Particulate $\mathrm{Hg}$}

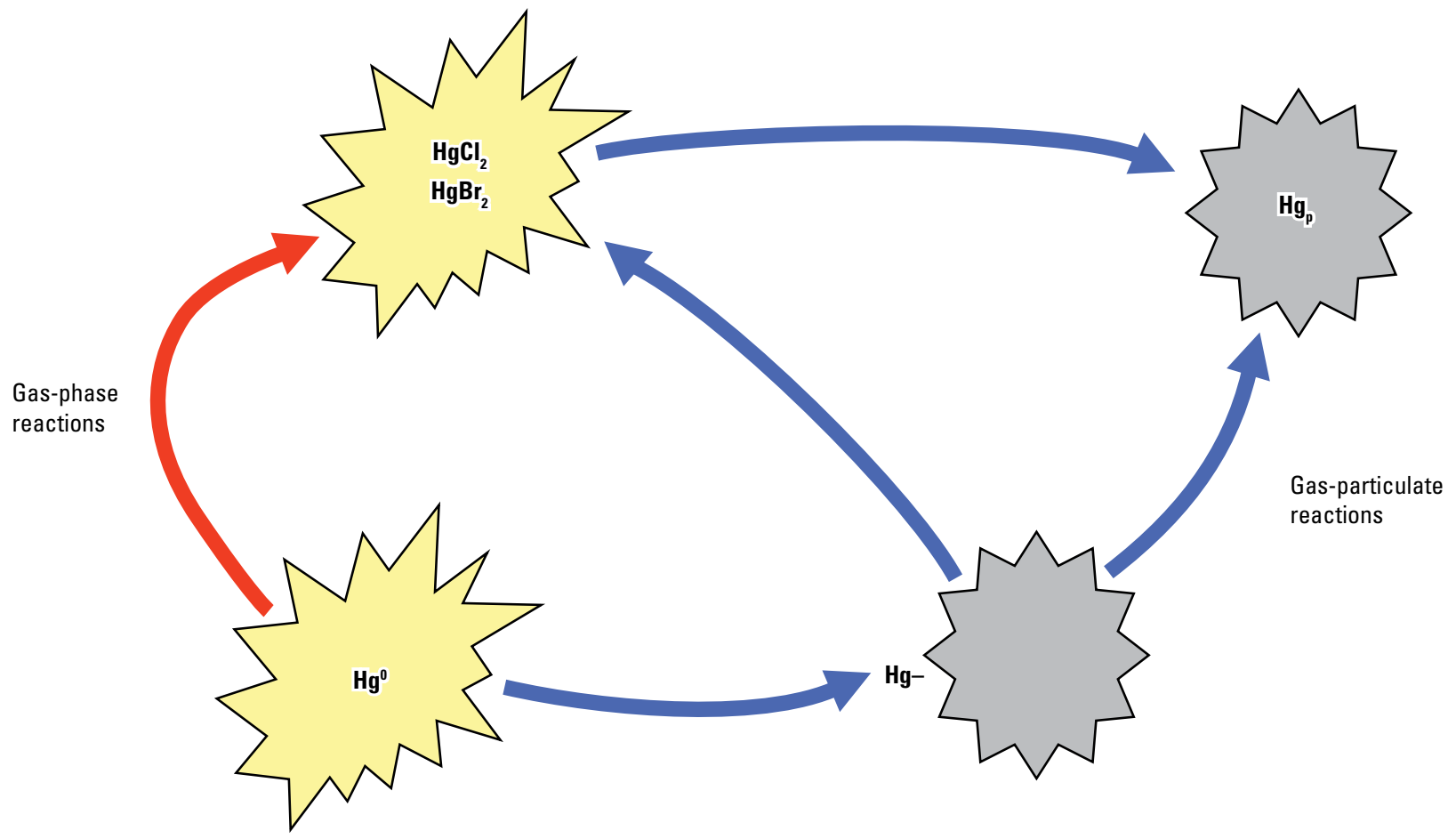

Figure 4. Diagram showing the pathways for mercury $(\mathrm{Hg})$ during coal combustion, and the pathways for mercury oxidation as the combustion gas cools. In reactions taking place in the flame (shown in red), all of the mercury from coal is released into the flue gas as elemental mercury $\left(\mathrm{Hg}^{0}\right)$; in oxidation reactions, which occur primarily as temperatures decrease (shown in blue), some of the $\mathrm{Hg}^{0}$ in the boiler becomes oxidized mercury $\left(\mathrm{Hg}^{2+}\right)$ by reacting with halogens (primarily bromine and chlorine), forming gaseous mercury-halogen complexes such as mercuric chloride (also "mercury II chloride") $\left(\mathrm{HgCl}_{2}\right)$, or mercuric bromide (also "mercury II bromide") ( $\left.\mathrm{HgBr}_{2}\right)$. Mercury oxidation can also take place by reactions between $\mathrm{Hg}^{0}$ and the surfaces of particles, especially if any unburned carbon is present suspended in the flue gas. Oxidized mercury formed by either of these two processes can become trapped on particle surfaces, especially on unburned carbon, thereby forming particulate mercury $\left(\mathrm{Hg}_{\mathrm{p}}\right)$. Gaseous elemental mercury thus oxidized is water soluble and can be removed by existing scrubbers that were initially designed to remove sulfur dioxide $\left(\mathrm{SO}_{2}\right)$. Particulate mercury (mercury that is bound to particles) can be captured by airpollution control devices designed to limit particle emissions. Halogens such as bromine and chlorine promote mercury oxidation, thereby allowing a portion of the mercury to be captured and prevented from entering the atmosphere. 


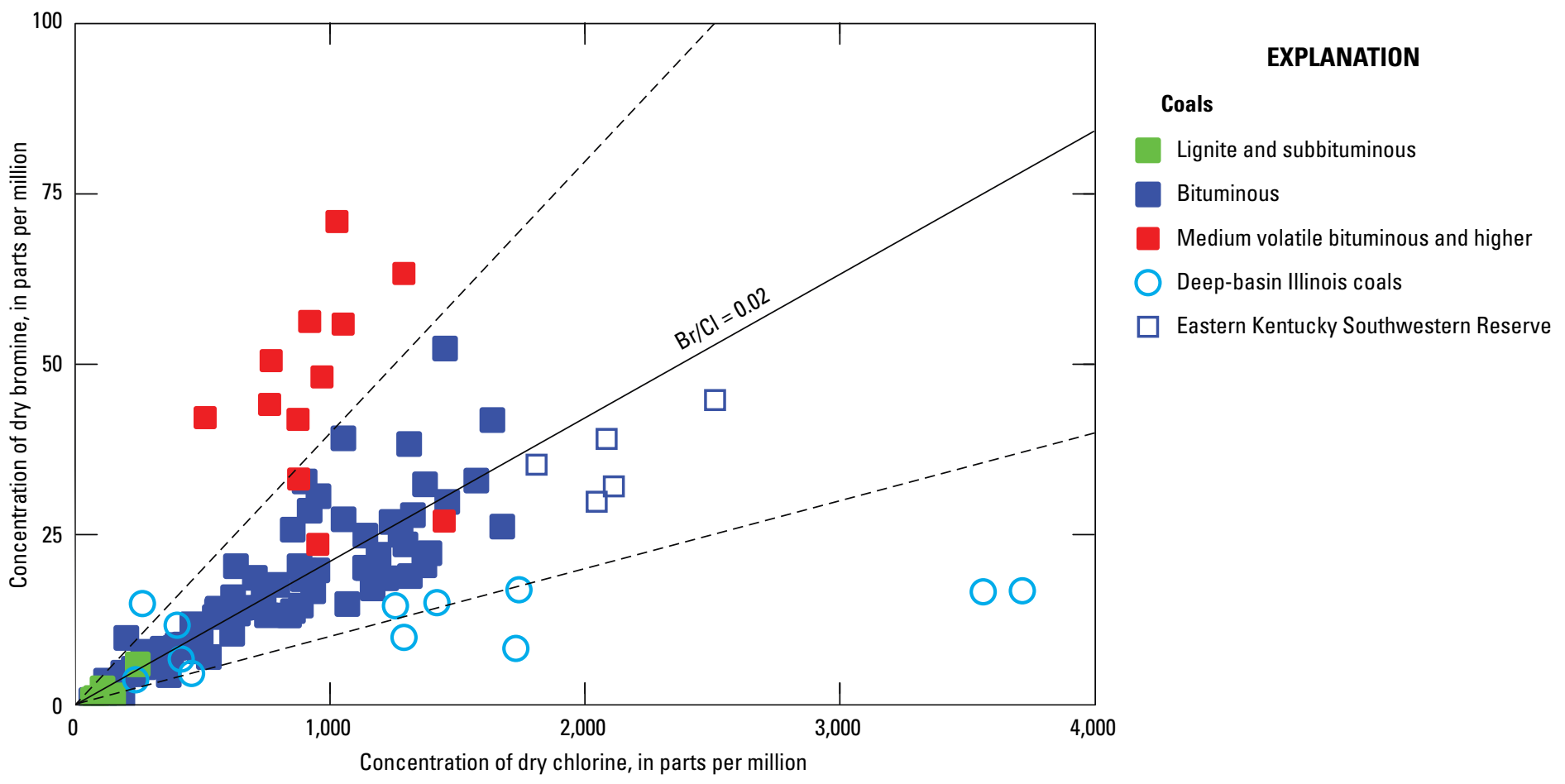

Figure 5. Scatter-plot showing average chlorine $(\mathrm{Cl})$ and bromine (Br) contents, in parts per million (ppm), for various ranks (grades) of coal produced in 110 U.S. counties. Those with lower rank coal (lignite, subbituminous) are green, bituminous coal are blue, and higher rank coal (medium volatile bituminous and higher) are red. Contents of $\mathrm{Br}$ in coal are commonly about 2 percent of the $\mathrm{Cl}$ content $(\mathrm{Br} / \mathrm{Cl}=0.02)$, the ratio generally ranging from 1 to 4 percent (dashed lines indicate this

complexes much more readily captured by APCDs than is $\mathrm{Hg}^{0}$ by itself. Chlorine is the most abundant halogen in coal, and it has the largest influence on $\mathrm{Hg}$ oxidation and capture. Bromine, which is heavier than $\mathrm{Cl}$, is much less abundant in most coals than $\mathrm{Cl}$ (fig. 5), but heavy halogens such as $\mathrm{Br}$ are proportionally more effective as $\mathrm{Hg}$ oxidants than lighter halogens such as $\mathrm{Cl}$. The actual proportion of $\mathrm{Hg}$ that conventional APCDs capture depends on the type of coal that is burned, the type and set-up of APCDs, the halogen content of that coal, and the flue gas temperature. Mercury-specific approaches, such as adding sorbents (materials that have the capacity to adsorb) containing halogens to the boiler, may be used to achieve greater reductions of $\mathrm{Hg}$ under MATS (Granite and others, in press).

Low-rank coals such as lignite generally have lower $\mathrm{Cl}$ contents than higher rank coals such as bituminous coal (fig. 5). The halogen content of coal is also controlled to a large degree when coal interacts with groundwater before being mined. It is normal for the salinity of groundwater to increase with depth, due to chemical exchange with geologic formations. For example, in the Illinois Basin, where coal has been sampled together with such formation water, there is an excellent correspondence between $\mathrm{Cl}$ in the coal and that in the water (Gluskoter and Rees, 1964). Similarly, in the Appalachian Basin, Cl content of coal increases with the age of coal-bearing geologic formations, which in general increase with depth in the basin (Bragg and others, 1991; table 2). Halogens are desirable for their capacity range). In some deep-basin Illinois coals (open circles), and in coals from the Southwestern Reserve District of eastern Kentucky (open squares), the interaction of coal with saline brines elevated $\mathrm{Cl}$ contents. $\mathrm{Br} / \mathrm{Cl}$ ratios are less consistent for the higher rank coals (medium volatile bituminous and higher). Data from COALQUAL, Bragg and others (1998), and Illinois State Geological Survey (2007).

to promote $\mathrm{Hg}$ capture, but $\mathrm{Cl}$ contents in the deepest coals, in Illinois and elsewhere, may be so high that they cause corrosion of utility boilers, and therefore are not usable. If these Cl-rich coals could potentially be used to blend with halogen-poor coal, their capacity to promote $\mathrm{Hg}$ capture could be increased.

Table 2. Mean chlorine content of coal by formation in order of increasing age in the central Appalachian Basin, Pennsylvania, and West Virginia, United States.

[From Bragg and others (1991). ppm, parts per million]

\begin{tabular}{llcc}
\hline \multicolumn{1}{c}{ Age } & \multicolumn{1}{c}{ Formation } & $\begin{array}{c}\text { Number of } \\
\text { samples }\end{array}$ & $\begin{array}{c}\text { Mean', } \\
\text { in ppm }\end{array}$ \\
\hline Lower Permian(?) & Dunkard Group & 44 & 162 \\
Upper Pennsylvanian & Monongahela & 73 & 477 \\
Upper Pennsylvanian & Conemaugh & 41 & 828 \\
Middle Pennsylvanian & Allegheny & 709 & 1,097 \\
Middle Pennsylvanian & Kanawha $^{2}$ & 36 & 1,408 \\
Lower Pennsylvanian & New River $^{2}$ & 56 & 1,503 \\
\hline
\end{tabular}

${ }^{1}$ Detection limit is $100 \mathrm{ppm}$. Samples in which chlorine was not detected are assumed to contain 70 percent of the detection limit.

${ }^{2}$ Samples are from southern West Virginia; all other samples are from Pennsylvania. 


\section{Summary}

The distribution of $\mathrm{Hg}$ and of halogens in coal is among the most important factors in determining the amount of $\mathrm{Hg}$ emitted to the atmosphere by coal combustion. New EPA rules are expected to limit $\mathrm{Hg}$ emissions from coal-fired utility power stations in the United States. These rules are the result of detailed sampling of U.S. coal and powerplant emissions. The EPA databases show trends in U.S. coal use, such as coal preparation and the shift to greater use of low-sulfur Western coals, which are not evident in COALQUAL, the USGS compilation for in-ground coal data. Nonetheless, COALQUAL remains useful in showing compositional differences among U.S. coals and in comparing international coal data. For China, recent compilations are sufficient to estimate mean $\mathrm{Hg}$ contents on a nationwide basis, and these results indicate that the $\mathrm{Hg}$ content of Chinese coals is comparable on average to that of in-ground coal in the United States as determined by the USGS. This finding contradicts earlier estimates of $\mathrm{Hg}$ in Chinese coal, which had suggested that Chinese coals contained more $\mathrm{Hg}$ than those in the United States. Less is known about the Hg content of coal in some of the most important coal-producing countries. New studies that assess the $\mathrm{Hg}$ and halogen contents of commercial coals, such as those conducted on U.S. coals by the EPA and the USGS, would allow countries elsewhere in the world to compile reliable data that would enable them to limit the proportion of $\mathrm{Hg}$ emitted by powerplants during coal combustion.

\section{References Cited}

Belkin, H.E., Zheng, B., and Finkelman, R.B., 2006, Mercury in coal from the People's Republic of China [abs.]: International Conference on Mercury as a Global Pollutant, 8th, Madison, Wis., 2006, p. 83-84.

Bragg, L.J., Finkelman, R.B., and Tewalt, S.J., 1991, Distribution of chlorine in United States coal, in Stringer, J., and Banerjee, D.D., eds., Chlorine in coal: Amsterdam, Elsevier, p. 3-10.

Bragg, L.J., Oman, J.K., Tewalt, S.J., Oman, C.L., Rega, N.H., Washington, P.M., and Finkelman, R.B., 1998, Coal quality (COALQUAL) database, version 2.0: U.S. Geological Survey Open-File Report 97-134 CD-ROM.

Dai, S., Ren, D., Chou, C.-L., Finkelman, R.B., Seredin, V.V., and Zhou, Y., 2012, Geochemistry of trace elements in Chinese coals-A review of abundances, genetic types, and impacts on human health and industrial utilization: International Journal of Coal Geology, v. 94, p. 3-21.
Gluskoter, H.J., and Rees, O.W., 1964, Chlorine in Illinois coal: Illinois State Geological Survey Circular 372, 23 p.

Granite, E.J., Pennline, H.W., and Senior, C.L., eds., in press, Mercury emissions control for coal-derived gas streams: Berlin, Wiley-VCH.

Illinois State Geological Survey (ISGS), 2007, Coal mines, coal geology and resource data online; Illinois coal quality data: Illinois Geological Survey, accessed April 19, 2012, at http://www.isgs.uiuc.edu/maps-data-pub/coal-maps/stratdatabase/coal-quality-nonconf.xls.

International Energy Agency (IEA), 2011, Key world energy statistics: International Energy Agency, 80 p., accessed February 27, 2012, at http://www.iea.org/textbase/nppdf/free/2011/ key_world_energy_stats.pdf.

Kolker, Allan, and Quick, J.C., in press, Mercury and halogens in coal, in Granite, E.J., Pennline, H.W., and Senior, C.L., eds., Mercury emissions control for coal-derived gas steams: Berlin, Wiley-VCH.

Tewalt, S.J., Bragg, L.J., and Finkelman, R.B., 2001, Mercury in U.S. coal-Abundance, distribution, and modes of occurrence: U.S. Geological Survey Fact Sheet 095-01, 4 p.

Tewalt, S.J., Belkin, H.E., SanFilipo, J.R., Merrill, M.D., Palmer, C.A., Warwick, P.D., Karlsen, A.W., Finkelman, R.B., and Park, A.J., comps., 2010, Chemical analyses in the world coal quality inventory, version 1: U.S. Geological Survey OpenFile Report 2010-1196, 4 p.

U.S. Environmental Protection Agency (EPA), 2011a, Mercury and air toxics standards, cleaner power plants, accessed April 19, 2012, at http://www.epa.gov/mats/powerplants.html.

U.S. Environmental Protection Agency (EPA), 2011b, Air toxics standards for utilities - MATS ICR data (EGU_ ICR_part I_and_part II), accessed March 23, 2012, at http://www.epa.gov/ttn/atw/utility/utilitypg.html.

U.S. Environmental Protection Agency (EPA), 2011c, Air toxics standards for utilities - MATS ICR data (EGU ICR part III) ACCESS data file, accessed March 23, 2012, at http://www.epa.gov/ttn/atw/utility/utilitypg.html.

U.S. Environmental Protection Agency (EPA), 2012, National emission standards for hazardous air pollutants from coal-and oil-fired electric utility steam generating units and standards of performance for fossil-fuel-fired electric utility, industrialcommercial-institutional, and small industrial-commercialinstitutional steam generating units: Federal Register, v. 77, no. 32, February 16, p. 9304-9513, accessed April 19, 2012, at http://www.gpo.gov/fdsys/pkg/FR-2012-02-16/ pdf/2012-806.pdf.

\section{For more information, please contact}

Allan Kolker

U.S. Geological Survey

12201 Sunrise Valley Drive

Mail Stop 956

Reston, VA 20192

Telephone: (703) 648-6418

Email: akolker@usgs.gov

\section{By Allan Kolker, Jeffrey C. Quick, ${ }^{2}$ Connie L. Senior, ${ }^{3}$ and Harvey E. Belkin ${ }^{1}$}

${ }^{1}$ U.S. Geological Survey.
${ }^{2}$ Utah Geological Survey.
${ }^{3}$ ADA Environmental Solutions, Inc. 